\title{
Sulfur isotopes in otoliths allow discrimination of anadromous and non-anadromous ecotypes of sockeye salmon (Oncorhynchus nerka)
}

\author{
Lyse Godbout • Marc Trudel • James R. Irvine • \\ Chris C. Wood • Marty J. Grove • \\ Axel K. Schmitt • Kevin D. McKeegan
}

Received: 5 November 2009 / Accepted: 27 June 2010/Published online: 29 July 2010

(C) The Author(s) 2010. This article is published with open access at Springerlink.com

\begin{abstract}
Oncorhynchus nerka occur both as anadromous sockeye salmon that spend most of their life in the ocean, and as non-anadromous kokanee salmon that remain in fresh water their entire lives. We assessed whether stable isotopes of sulfur $\left(\delta^{34} S\right)$ in otoliths could be used to distinguish sockeye salmon and kokanee ecotypes that are otherwise difficult to identify when they share a common freshwater rearing environment. We also investigated the chemical link between salmon and their diet by measuring $\delta^{34} \mathrm{~S}$ in various fish tissues (eggs, muscle, scales) and zooplankton. $\delta^{34} \mathrm{~S}($ mean $\pm \mathrm{SE})$ in sockeye salmon eggs $(18.7 \pm 0.4 \%$ o $)$ and marine zooplankton $(20.5 \pm 0.1 \%$ ) were enriched by $10-14 \%$ compared with kokanee eggs and freshwater zooplankton. $\delta^{34} \mathrm{~S}$ in the otolith
\end{abstract}

L. Godbout $(\bowtie) \cdot$ M. Trudel $\cdot$ J. R. Irvine $\cdot$ C. C. Wood Fisheries and Oceans Canada,

Pacific Biological Station, 3190 Hammond Bay Road,

Nanaimo, BC V9T 6N7, Canada

e-mail: lyse.godbout@dfo-mpo.gc.ca

\section{J. Grove}

Department of Geological and Environmental Sciences, Stanford University,

Stanford, CA 94305, USA

A. K. Schmitt • K. D. McKeegan

Department of Earth and Space Sciences,

University of California, Los Angeles,

Los Angeles, CA 90095-1567, USA cores of sockeye salmon $(19.2 \pm 0.7 \%$ ) and kokanee salmon $\left(5.3 \pm 1.1 \%\right.$ o were similar to $\delta^{34} \mathrm{~S}$ in marine and freshwater zooplankton, respectively, indicating that the core is derived from maternal yolk tissue and reflects the maternal diet. $\delta^{34} \mathrm{~S}$ in the freshwater growth zone of otoliths did not differ significantly between sockeye $(5.9 \pm 1.1 \%$ ) and kokanee salmon (4.4 \pm $1.2 \%$ ), and was similar to freshwater zooplankton. The mean difference between $\delta^{34} \mathrm{~S}$ in the otolith core and first year of growth was $13.3 \pm 1.4 \%$ for sockeye and $0.65 \pm 1.3 \%$ for kokanee salmon. A quadratic discriminant function developed from measurements of $\delta^{34} \mathrm{~S}$ in otoliths of known maternal origin provided perfect classification rates in cross-validation tests. Thus, sulfur isotope ratios in otoliths are effective in discriminating between anadromous and nonanadromous ecotypes of $O$. nerka.

Keywords Oncorhynchus nerka - Ecotypes · Sockeye salmon $\cdot$ Kokanee $\cdot$ Otolith microchemistry $\cdot \delta^{34} \mathrm{~S}$

\section{Introduction}

Declining populations of anadromous salmon in western North America have prompted implementation of conservation measures including freshwater habitat restoration and hatchery supplementation (Lackey et al. 2006). The success of these approaches has been difficult to evaluate when visually indistinguishable anadromous and non- 
anadromous ecotypes co-exist in freshwater. For example, Oncorhynchus nerka commonly occurs both as anadromous sockeye salmon (hereafter called "sockeye") which spend most of their life in the ocean, typically rearing in fresh water for less than 2 years, and as non-anadromous "kokanee" which live in fresh water for their entire lives. Although these ecotypes are typically genetically distinct, genetic analyses are sometimes inadequate to discriminate them when differentiation is limited or when hybridization occurs (Foote et al. 1989; Taylor et al. 1996; Wood et al. 2008).

Chemical markers including elemental ratios from otoliths such as $\mathrm{Sr}$ :Ca can be used to discriminate sympatric populations (Kalish 1990). However, studies that have used otolith Sr:Ca to infer maternal origin of salmonids have had mixed success (Rieman et al. 1994; Volk et al. 2000). On the other hand, Zimmerman and Reeves (2000, 2002) were successful at discriminating anadromous and non-anadromous Oncorhynchus mykiss. The limitation is due to the fact that $\mathrm{Sr}: \mathrm{Ca}$ in the core of an otolith does not depend solely on the maternal origin but also on background concentrations in freshwater, migratory distances, and the length of the time in freshwater prior to spawning (Donohoe et al. 2008). $\delta^{34} \mathrm{~S}$ offers a promising alternative to elemental signatures since organic sulfur in animal tissue is derived from organic sulfur in their diet and $\delta^{34} \mathrm{~S}$ differs between marine and freshwater environments with little to no trophic fractionation and temperature effect (Peterson and Fry 1987; Hesslein et al. 1991; Barnes and Jennings 2007). $\delta^{34} \mathrm{~S}$ in marine prey and sea water consistently tends to be about $20 \%$ (Goldhaber and Kaplan 1974; Thode 1991). In contrast, $\delta^{34} \mathrm{~S}$ signatures in freshwater vary according to watershed geology, anthropogenic inputs, and atmospheric deposition (Mitchell et al. 2001) and tend to be lower than those in the ocean.

The contribution of marine and freshwater prey in the diet of salmonids is expected to be reflected by the chemical composition in their tissues (DeNiro and Epstein 1978; Hesslein et al. 1993; Doucett et al. 1999a), as well as in the protein matrix of their otoliths (Weber et al. 2002). Although proteins for less than $5 \%$ of an otolith's weight, they play an important role in the morphogenesis of the microcrystalline calcium carbonate of otoliths (Kang et al. 2008). Sulfur-based amino acids, such as cysteine, are in four of the five proteins found in otoliths, and these are important for the proper folding and stabilization of a protein's three-dimensional structure (R. Kollamar, SUNY Downstate Medical Center, NY, USA, pers. comm.). Because anadromous ecotypes accumulate the bulk of their chemical constituents during their ocean life (Burgner 1991; Naiman et al. 2002), their eggs, and to a lesser extent their alevins are expected to carry a marine $\delta^{34} \mathrm{~S}$ signature until the start of exogenous feeding, and then again when they migrate to sea. In contrast, non-anadromous ecotypes are expected to carry a freshwater $\delta^{34} \mathrm{~S}$ signature throughout their lives. $\delta^{34} \mathrm{~S}$ has the additional advantage of potentially being useful to discriminate hatchery from wild fish (Weber et al. 2002).

The ability to determine the dietary history of anadromous fish using otolith $\delta^{34} \mathrm{~S}$ signatures was demonstrated by Weber et al. (2002). However, little is known of the variability in $\delta^{34} \mathrm{~S}$ signatures as Weber et al. (2002) analyzed only the otoliths of two salmon: a wild Chinook salmon (O. tchawytsha) and a hatchery-reared Chinook salmon. Also, when young salmon and kokanee co-exist in ectogenic meromictic lakes, which are not uncommon in coastal British Columbia (Walker and Likens 1975), complications may result from the intrusion of saltwater. In ectogenic meromictic lakes, water below the chemocline contains marine-derived sulfur, which may be brought to the surface by methane production or strong wind events and incorporated in the food web via primary producers. Zooplankton may thus serve as a direct vector of marine $\delta^{34} \mathrm{~S}$ to anadromous and non-anadromous fry and smolt ecotypes.

The main objective of this study was to expand on the work of Weber et al. (2002) by assessing the usefulness of $\delta^{34} \mathrm{~S}$ to discriminate anadromous and non-anadromous ecotypes of $O$. nerka, on the basis of their maternal origin, as either marine or freshwater. This was accomplished by analyzing $\delta^{34} \mathrm{~S}$ in otoliths of adult kokanee and sockeye from several British Columbia lakes, including a meromictic lake. In addition, we measured the $\delta^{34} \mathrm{~S}$ signature in fish eggs, muscles, scales and zooplankton, the primary prey consumed by kokanee and sockeye. To illustrate the utility of this approach, we used $\delta^{34} \mathrm{~S}$ to assess the maternal origin of a sample of $O$. nerka collected from a meromictic lake, where both ecotypes live in sympatry. 


\section{Methods}

\section{Collection}

To assess the applicability of $\delta^{34} \mathrm{~S}$ to discriminate among ecotypes, we proceeded in four steps. First, we collected freshwater and marine zooplankton to characterize baseline $\delta^{34} \mathrm{~S}$. Second, we measured $\delta^{34} \mathrm{~S}$ in various tissues of adult sockeye and kokanee as well as juvenile sockeye caught in the marine environment and contrasted these values to zooplankton $\delta^{34} \mathrm{~S}$ to assess the trophic transfer in $\delta^{34} \mathrm{~S}$ in aquatic food chains. Third, we measured $\delta^{34} \mathrm{~S}$ in the otoliths of adult sockeye and kokanee of known maternal origin. Finally, we contrasted the $\delta^{34} \mathrm{~S}$ signature in otoliths of $O$. nerka of unknown origin to those of adult kokanee and sockeye to assess their origin.

Freshwater and marine zooplankton samples were collected using $100 \mu \mathrm{m}$ and $250 \mu \mathrm{m}$ mesh nets, respectively (Table 1). Marine zooplankton samples were collected along the West Coast of Vancouver Island, in Queen Charlotte Sound, and Dixon Entrance (WCoastBC, Fig. 1, Table 1). Euphausiids were collected from Barkley Sound on the West Coast of Vancouver Island (Table 1).

Adult sockeye were caught in Sproat and Nimpkish lakes in 2006, and Sakinaw Lake in 2003 (Fig. 1, Table 1) during their spawning migration to their natal freshwater system. Sproat and Nimpkish are large oligotrophic dimictic lakes, while Sakinaw Lake is meromictic. The latter is a stably stratified ex-fjord, which became isolated from the Strait of Georgia approximately 11,000 years ago by sills uplifted by post-glacial isostatic rebound (Perry and Pedersen 1993). The lake consists of two basins: one relatively shallow (49 m) and wholly fresh, and the other a deep $(\sim 140 \mathrm{~m})$ meromictic basin that contains relict seawater below the upper $30 \mathrm{~m}$. The lake is on average $2 \mathrm{~m}$ above mean sea level, and a high level of sulfate is present in the oxic part of the water column (up to $65 \mu \mathrm{M}$ ) (Perry and Pedersen 1993). The water level of the lake is regulated by a small dam on the outflow near the ocean.

Nine kokanee were collected from Ruby Lake, Alouette Reservoir, and Sakinaw Lake (Fig. 1) in the fall of 2005, fall of 2007, and winter of 2008, respectively (Table 1). Ruby Lake and Alouette Reservoir have obstructions that prevent anadromous fish from entering. Ruby Lake is upstream of Sakinaw Lake while Alouette Reservoir drains into the lower Fraser River. Kokanee collected from Sakinaw Lake were mature females, recognizable by their shape, color, and relatively small size. Kokanee were collected using a $23 \mathrm{~mm}$ mesh size purse seine, except at Alouette Lake where gillnets were used. Ten additional specimens of unknown origin were collected in Sakinaw Lake in the fall of 2005 and winter of 2008 (Table 1) to test the utility of $\delta^{34} \mathrm{~S}$ to assess the maternal origin from field samples. We were uncertain whether these relatively large $(>18 \mathrm{~cm})$ fish were sockeye or kokanee. Juvenile salmon were collected along the coast of British Columbia using a mid-water trawl in the fall of 2007 (Table 1).

Although preservation techniques varied, these seem to have little impact on $\delta^{34} \mathrm{~S}$ (Edwards et al. 2002). Fish tissues from kokanee, sockeye and juvenile salmon from the $\mathrm{BC}$ coast were either from fresh or frozen fish, except for kokanee samples from Alouette Lake that were preserved in $95 \%$ ethanol. Zooplankton samples were either fresh samples, preserved in $3.7-5 \%$ formalin, or preserved in $95 \%$ ethanol.

Sample preparation and chemical analysis

Fish scales were sonified for $5 \mathrm{~min}$ in 3\% ultrapure hydrogen peroxide to loosen debris, rinsed three times with Milli-Q water, dried, and stored in tight vials. Fish eggs, fish muscle, whole fish, and zooplankton samples were dried in an oven at $68^{\circ} \mathrm{C}$, ground to a fine powder with a pestle and mortar, and stored in airtight vials prior to processing. Except for the marine zooplankton and coastal juvenile salmon, sulfur stable isotope analyses were conducted by Iso-Analytical Limited (Sandbach, UK). Tin capsules containing $2 \mathrm{mg}$ of sample or reference material plus $4 \mathrm{mg}$ of vanadium pentoxide were processed with an automatic sampler coupled to a Europa Scientific 20-20 isotope ratio mass spectrometer (Crewe, UK). Results are presented in delta notation (in per mil \%o) using V-CDT (troilite of the Canyon Diablo meteorite) as a reference. Samples were processed with at least $20 \%$ replication (i.e., two subsamples were analyzed from $20 \%$ of the samples), and the mean of the two subsamples was used in the analysis. The greatest difference between any pair of replicates was $0.82 \%$ o with a mean difference of $0.094 \pm 0.05 \%$ o (1SE). Three inorganic standards were used to set the calibration scale and two organic standards were run routinely to check 
Table 1 Type and number of samples analyzed by collection site and date $(\mathrm{Z}=$ zooplankton, $\mathrm{K}=$ kokanee, $\mathrm{S}=$ sockeye, Unk $=$ unknown)

\begin{tabular}{|c|c|c|}
\hline Location & Sample type & Collection month/year (no. of samples) \\
\hline \multirow[t]{4}{*}{ Ruby Lake } & $\mathrm{Z}$ & 10/08(3), 06/09(1), 09/09(1) \\
\hline & K eggs & $11 / 07(3)$ \\
\hline & K otoliths & $11 / 07(1), 11 / 05(3)$ \\
\hline & $\mathrm{K}$ muscle & $11 / 07(4)$ \\
\hline \multirow[t]{9}{*}{ Sakinaw Lake } & $\mathrm{Z}$ & 06/06(3), 07/06(5), 09/06(5),07/05(2), 10/05(2) \\
\hline & Unk otoliths & $11 / 05(8), 01 / 08(2)$ \\
\hline & $\mathrm{K}$ muscle & $01 / 08(3)$ \\
\hline & K whole fish & $01 / 08(4)$ \\
\hline & $\mathrm{K}$ otoliths & $01 / 08(2)$ \\
\hline & K eggs & $09 / 05(1), 01 / 08(5)$ \\
\hline & K scales & $11 / 09(3)$ \\
\hline & S eggs & $09 / 05(1)$ \\
\hline & S otoliths & $09 / 03(2)$ \\
\hline \multirow[t]{4}{*}{ Sproat Lake } & $\mathrm{Z}$ & 08/08(1), 09/08(1),10/08(1) \\
\hline & S otoliths & $06+07 / 06(5)$ \\
\hline & S scales & $06+07 / 06(2)$ \\
\hline & S eggs & $06+07 / 06(4)$ \\
\hline \multirow[t]{4}{*}{ Alouette Reservoir } & $\mathrm{Z}$ & 05/07(1), 06/07(1), 08/07(1), 09/07(1) \\
\hline & $\mathrm{K}$ otoliths & $10 / 07(3)$ \\
\hline & K scales & $10 / 09(3)$ \\
\hline & K eggs & $10 / 09(2)$ \\
\hline \multirow[t]{3}{*}{ Nimpkish Lake } & S otoliths & $07 / 06(5)$ \\
\hline & Z (Woss Lake) & 07/03(1), 08/03(1), 09/03(1) \\
\hline & S eggs & $10 / 06(4)$ \\
\hline WCVI \& QCI & $\mathrm{Z}$ & $10 / 07(8), 12 / 07(2), 12 / 08(4), 12 / 08(2)$ \\
\hline Barkley Sound & Euphausiids & 09/05(1), 05/08(1) \\
\hline
\end{tabular}

accuracy. The reference material used was IA-R036 (Iso-Analytical working standard barium sulfate, $\delta^{34} \mathrm{SV}$ $\mathrm{CDT}=20.74 \%$ ) calibrated and traceable to NBS-127 (barium sulfate, $\delta^{34} \mathrm{SV}-\mathrm{CDT}=20.3 \%$ ). IAEA-S-1 (silver sulfide, $\delta^{34} \mathrm{SV}-\mathrm{CDT}=0.3 \%$ ), IA-R025 (Iso-Analytical working standard barium sulfate, $\delta^{34} \mathrm{SV}-\mathrm{CDT}=8.53 \%$, calibrated and traceable to NBS-127), and IA-R036 were used for calibration and correction of the ${ }^{18} \mathrm{O}$ contribution to the $\mathrm{SO}^{+}$ion signal. Organic standards, more similar to fish samples than inorganic standards, were also used for quality control. IA-R036 and IAR027 (Iso-Analytical working standard whale baleen, $\delta^{34} \mathrm{SV}-\mathrm{CDT}=16.3 \%$, calibrated and traceable to NBS-
127) showed analytical precision of $0.036 \%$ and $0.039 \%$ o (1SE, $n=11$ ).

Marine zooplankton and coastal juvenile salmon were freeze-dried, then oven-dried and homogenised. Tin capsules were packed with 7-9 mg of sample and $2 \mathrm{mg}$ of vanadium pentoxide and analyzed on a CFIRMS Costech EA-Thermo Delta V IRMS at University of Victoria. Bovine Liver from the National Institute of Standards and Technology was run as the standard $\left(\delta^{34} \mathrm{~S} 6.948 \pm 0.3 \%\right.$, $\left.1 \mathrm{SE}\right)$.

Otoliths were cleaned in de-ionized water, dried, embedded in resin (Buehler 20-8130 epoxide resin with Buehler 20-8132 hardener), cured overnight at 
Fig. 1 Sampling locations in coastal British Columbia (west coast of Vancouver Island, Barkley Sound, Queen Charlotte Sound, Dixon Entrance) for marine zooplankton (solid circles) and juvenile salmon (open circles). Location of the study lakes for sockeye (Sakinaw, Ruby, Alouette, Sproat and Nimpkish lakes) and kokanee (Ruby and Alouette lakes). Note that sockeye and kokanee are sympatric in Sakinaw Lake

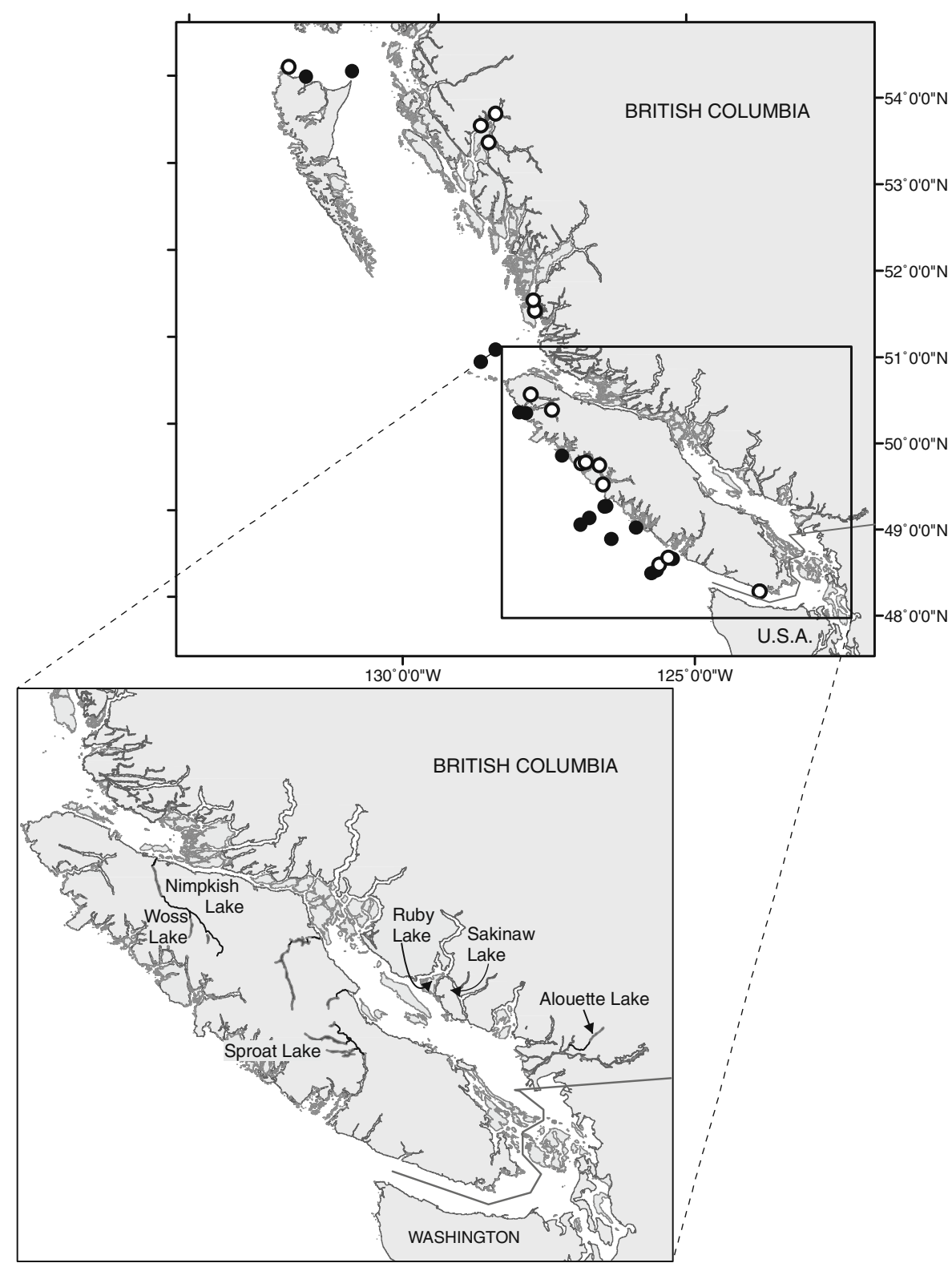

$62^{\circ} \mathrm{C}$ in a drying oven, and polished on both sides to expose the core area and banding. The grinding axis was through the core. Composition of sulfur isotopes in the cores to the outer edges of otoliths was analyzed by secondary ion mass spectrometry (SIMS) at the University of California in Los Angeles using a CAMECA ims 1270. Sulfur isotopic compositions were determined by sputtering otoliths with a $\sim 2 \mathrm{nA}$ to $3 \mathrm{nA}$ cesium $\left(\mathrm{Cs}^{+}\right)$primary ion beam with a $25 \mu \mathrm{m}$ spot diameter. Negative secondary ions were extracted at $10 \mathrm{kV}$, with an energy band-pass of $50 \mathrm{eV}$, and analyzed at a mass resolving power $(\mathrm{M} / \Delta \mathrm{M})$ of 4000 , sufficient to resolve hydride interferences. A presputter time of $120 \mathrm{~s}$ was applied, during which centering of the secondary ions and the magnetic field setting was performed in an automated fashion. ${ }^{34} \mathrm{~S} /{ }^{32} \mathrm{~S}$ ratios were determined using a single electron multiplier detector and 30-magnet-cycles-per-spot analysis which gave an in-run analytical precision between $1 \%$ and $2 \%$. Intensities were corrected for 
dead-time (27 nsec), and isotopic ratios were expressed as $\delta^{34} \mathrm{~S}$ (V-CDT). Usually two analysis spots were placed in each of three zones: the core, the first year of growth, and the last year of growth. Identification of the zone corresponding to the core and first year of growth was based on the hatch check and first-feeding check (Marshall and Parker 1982). Additional measurements were obtained in the core area in order to monitor local heterogeneities. Instrumental mass fractionation was determined throughout each analytical session from replicate analysis of the outer edge of sockeye otolith assuming a marine ${ }^{34} \mathrm{~S} /{ }^{32} \mathrm{~S}$ of 0.04505 , or $\delta^{34} \mathrm{~S}(\mathrm{~V}-\mathrm{CDT})=+20 \%$ relative to $\mathrm{V}-\mathrm{CDT}{ }^{34} \mathrm{~S} /{ }^{32} \mathrm{~S}=0.044163$ (Ding et al. 2001). Analyses of fish of unknown maternal origin were interspersed with those of known maternal origin and isotopic data were corrected using the average instrumental mass fractionation factor from each analytical session. Instrumental mass fractionation for ${ }^{34} \mathrm{~S} /{ }^{32} \mathrm{~S}$ in otoliths shows only minor variability after exchange of samples in the analysis chamber, and reproduced well in two individual sessions separated by 1 year $(-14.8 \pm$ $0.4 \%$ in 2007 , and $-15.7 \pm 0.4 \%$ in 2008 ; all errors are $1 \mathrm{SE})$. It is also reasonable to apply the same instrumental mass fractionation for different regions of the otoliths and for different ecotypes (sockeye and kokanee) because they show similar S ion intensities, therefore suggesting that compositional variations (e.g., from different relative abundances of carbonate and organic matter) are minor.

\section{Statistical analysis}

Estimates of $\delta^{34} \mathrm{~S}$ in the otolith core, first year of growth and the difference between the core and first year of kokanee and sockeye otoliths were compared using ANOVA (Proc GLM, SAS Institute 2008). To evaluate the effectiveness of sulfur isotopes in identifying ecotypes of $O$. nerka, we performed discriminant function analysis (DISCRIM, SAS Institute version 9.2) using $\delta^{34} \mathrm{~S}$ from the core of ecotypes of known maternal origin. Before proceeding with discriminant function analysis, we tested for homogeneity of the within-group covariance matrices using a Bartlett's modification of the likelihood ratio test (Morrison 1976; Anderson 1984). The error rate was estimated via crossvalidation, where each observation was classified using a discriminant function computed from all observations, except for the observation being classified.

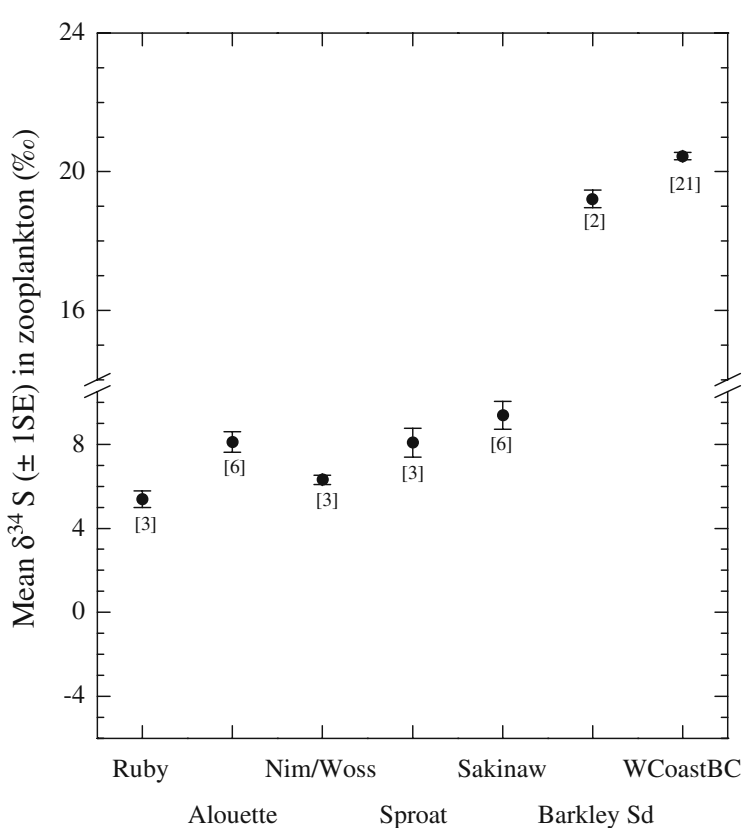

Fig. 2 Mean $\delta^{34} \mathrm{~S}( \pm 1 \mathrm{SE})$ in freshwater zooplankton, marine zooplankton from the west coast of British Columbia (WCoastBC), and in euphausids from Barkley Sound (Barkley $\mathrm{Sd})$. Number in brackets indicates the sample size

\section{Results and discussion}

$\delta^{34} \mathrm{~S}$ in zooplankton

Mean $\delta^{34} \mathrm{~S}$ in freshwater zooplankton ranged from $6.3 \%$ to $9.4 \%$ in the sockeye lakes, and from $6.2 \%$ to $8.1 \%$ in the kokanee lakes (Fig. 2). In contrast, the $\delta^{34} \mathrm{~S}$ signature in marine zooplankton off the west coast of British Columbia and of euphausiid samples from Barkley Sound averaged 20.5\%o and 18.5\%o, respectively (Fig. 2). Our values for both freshwater and marine zooplankton are within the range of those reported in the literature, providing further evidence that $\delta^{34} \mathrm{~S}$ signature differs substantially $(>10 \%$ ) between freshwater and marine ecosystems (Fig. 3).

Seasonal and interannual variation tended to be higher in freshwater than in the marine environment. Seasonal variation of $\delta^{34} \mathrm{~S}$ in freshwater zooplankton in Nimpkish/Woss Lake, Sproat Lake and Alouette Lake was up to $2.8 \%$. In the meromictic Sakinaw Lake, the overall mean $\delta^{34} \mathrm{~S}$ in freshwater zooplankton averaged $9.4 \%$ (Fig. 2). However, $\delta^{34} S$ in zooplankton varied among years and basins. In 2005, the mean $\delta^{34} \mathrm{~S}$ in zooplankton in the upper 


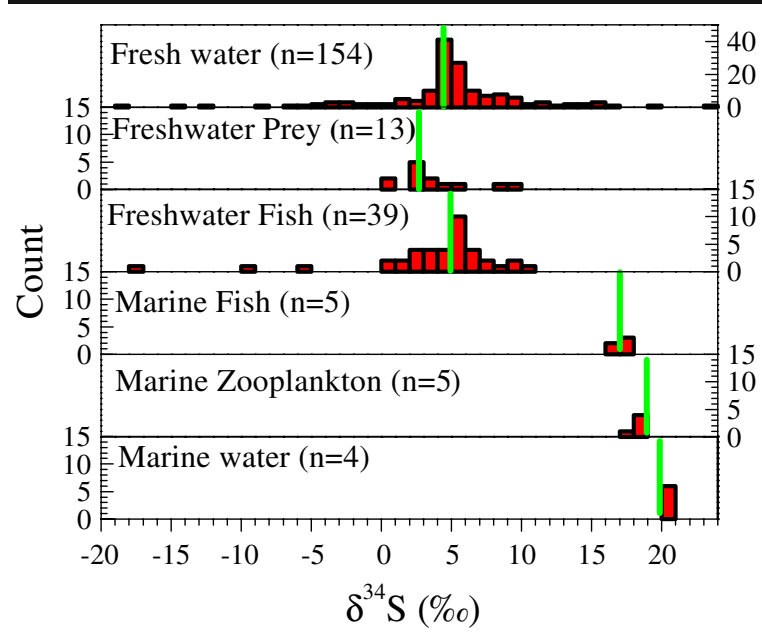

Fig. 3 Frequency distribution of stable isotope ratios of sulfur in freshwater sulfate, freshwater prey, freshwater fish, marine fish, marine zoo plankton and marine water sulfate obtained from the literature (Ault and Kulp 1959; Thode et al. 1961; Hartmann and Nielsen 1964; Sasaki 1972; Gormly and Sackett 1977; Rees et al. 1978; Fry 1983; Nriagu and Soon 1985; Peterson et al. 1985; Fuller et al. 1986; Fry 1988; Hesslein et al. 1988, 1991; Krouse and Herbert 1988; Nriagu et al. 1991; Andersson et al. 1992; Caron et al. 1996; Yang et al. 1996; MacAvoy et al. 1998; Chanton and Lewis 1999; Doucett et al. 1999a, b; Power et al. 2002; Weber et al. 2002; Spence and Telmer 2005; Calmels et al. 2007; Hoffman et al. 2007; Ethier et al. 2008; Wells et al. 2008; Croisetière et al. 2009; De Brabandere et al. 2009). Vertical bars correspond to the median value

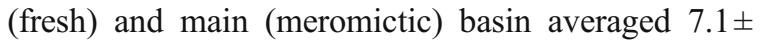
$0.2 \%$ ( $1 \mathrm{SE}$ ) and $7.6 \pm 0.5 \%$ ( $1 \mathrm{SE})$, respectively, compared to $9.4 \pm 0.2 \%$ ( $1 \mathrm{SE}$ ) and $11.1 \pm 0.4 \%$ o (1SE) in 2006. The interannual variability of $\delta^{34} \mathrm{~S}$ in zooplankton in Sakinaw Lake may reflect variable contributions of sulfur originating below the chemocline. Sulfur is present below the chemocline, but $\delta^{34} \mathrm{~S}$ values in the surface waters are much lower than typically found in the marine environment. Marine zooplankton samples averaged 20.5\% in March 2007, 20.7\% in October 2007 and 19.9\%o in March 2008. Therefore, during that time, seasonal and interannual variation was less than $1 \%$ for marine zooplankton.

$\delta^{34} \mathrm{~S}$ in mature sockeye and kokanee tissues

As expected, $\delta^{34} \mathrm{~S}$ varied little $(0.2-1 \%)$ between muscles and eggs of mature specimens within a given ecotype and ecosystem, probably because eggs are derived from protein and lipid matrices in the maternal muscle (Vander Zanden et al. 1998; Doucett et al. 1999a). Mean $\delta^{34} \mathrm{~S}$ in kokanee eggs and muscle ranged from $4 \%$ in Ruby Lake to $8 \%$ in Sakinaw Lake (Fig. 4). Sockeye eggs (18.7\%) or muscle (18.5\%) were enriched on average by $10 \%$ o to $14 \%$ relative to kokanee (Fig. 4). It is worth noting that for either sockeye or kokanee, scales had the same isotopic signature as eggs and muscle (Fig. 4).

The $\delta^{34} \mathrm{~S}$ in fish tissues (eggs, muscle, whole fish, and scales) pooled from sockeye and kokanee were linearly related to $\delta^{34} \mathrm{~S}$ in zooplankton. $\delta^{34} \mathrm{~S}$ in fish tissues was on average $1.6 \%$ lower than that found in zooplankton $\left(\delta^{34} \mathrm{~S}\right.$ pooled fish tissues samples $=-1.6 \pm$. $0.1 \%$ o (1SE) $+1 \delta^{34} \mathrm{~S}$ in zooplankton, $\mathrm{r}^{2}=0.98, n=33$ ) which is within the range reported by McCutchan et al. (2003, 2005). Barnes and Jennings (2007) reported slightly lower fractionation values ( $-1 \%$ to $0 \%$ ) between European sea bass muscle and their laboratory diet. Weber et al. (2002), also found lower fractionation $(<-0.5 \%)$ between muscles of juvenile Chinook salmon and their diet (either gut contents or hatchery feed). Our slightly higher values of fractionation suggest that our zooplankton samples might not have been wholly representative of the diet.

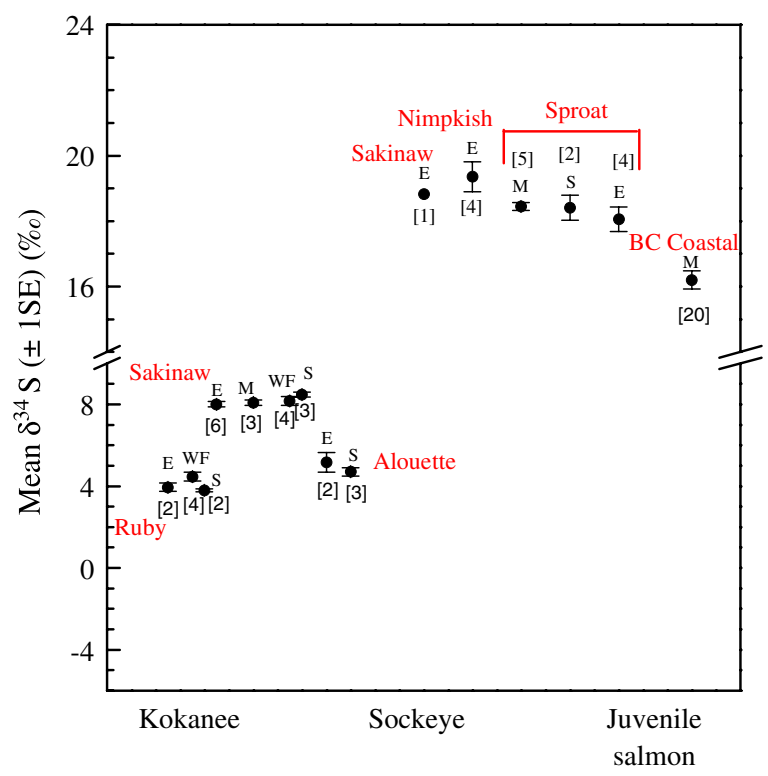

Fig. 4 Mean $\delta^{34} S( \pm 1 \mathrm{SE})$ in eggs (E), whole fish (WF), muscle (M) or fish scale (S) of kokanee and sockeye from the study lakes as well as from juveniles salmon caught along the west coast of British Columbia. Numbers in brackets indicate the sample size 
$\delta^{34} \mathrm{~S}$ in $\mathrm{BC}$ coastal juvenile's salmon

$\delta^{34} \mathrm{~S}$ of juveniles salmon caught in marine coastal water of British Columbia averaged 16.2\%o with values ranging from $12 \%$ ( 1 out of 20 ) to $17.4 \%$ (Fig. 4). $\delta^{34} \mathrm{~S}$ in juvenile salmon were enriched by 8 to $12 \%$ relative to kokanee (Fig. 4 ), 6 to $34 \%$ relative to other freshwater fishes (Fig. 3), but were on average 4\% lighter than the marine zooplankton (Fig. 2). All the juvenile salmon were caught at sea in October-November 2007, a time when seasonal and interannual variation was less than $1 \%$ o for marine zooplankton. Consequently, the $4 \%$ discrepancy in $\delta^{34} \mathrm{~S}$ between juveniles and the marine zooplankton is either due to fractionation of $\mathrm{S}$ between the fish and its diet, lack of equilibrium with the diet, or because the sampling locations of the marine zooplankton samples did not reflect the feeding habitats of the juveniles. The last option is a possibility since experimental work using European sea bass suggests that fractionation was minimal $(0 \%$ to $-1 \%$ ) under various ration levels and temperatures studied (Barnes and Jennings 2007).

\section{$\delta^{34} \mathrm{~S}$ in sockeye and kokanee otoliths}

The overall pattern of $\delta^{34} \mathrm{~S}$ in the core, first year of growth, and last year of growth of individual kokanee and sockeye is related to the maternal diet and the diet in their respective ecotypes (Fig. 5). For sockeye, a marine signature $\left(\delta^{34} \mathrm{~S}>17.2 \%\right)$ is present in both the core and last year of growth, whereas freshwater values $\left(\delta^{34} \mathrm{~S}<8 \%\right.$ ) persist throughout the otoliths of kokanee. Freshwater signatures are the most variable with differences between the extreme values of $0.8 \%$ o and $5.2 \%$ depending of the ecotype and ecosystem (Fig. 5). Yet, the mean $\delta^{34} \mathrm{~S}$ in the first year of growth did not differ significantly between sockeye (5.9\%o) and kokanee $(4.4 \%)(F=1.4, p>0.20)$. In contrast, the mean $\delta^{34} \mathrm{~S}$ in the core of the sockeye otoliths was $19.2 \%$ and significantly different $(F=122.3, p<$ $0.0001)$ than of kokanee $(5.3 \%)$. Furthermore, sockeye had a $13.3 \%$ difference of $\delta^{34} \mathrm{~S}$ between the core and the first year which was significantly $(F=45.2$, $p<0.0001)$ different than that for kokanee $(0.6 \%)$ reflecting differences between marine and freshwater zooplankton as the source of organic sulfur. Although the $\delta^{34} \mathrm{~S}$ in the various regions of an otolith correspond to the diet for each period of the life history, we, like

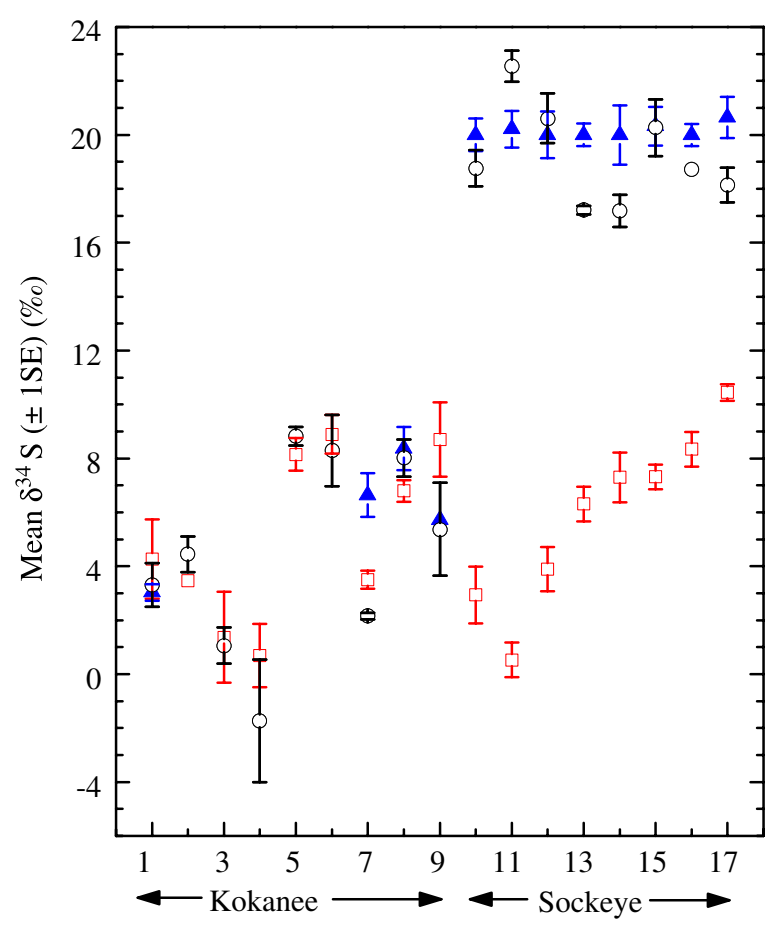

Fig. 5 Mean $\delta^{34} \mathrm{~S}( \pm 1 \mathrm{SE})$ in the core (open circle), first year of growth (hollow square), and last year of growth (solid triangle) of otoliths from $O$. nerka of known maternal origin in Ruby Lake (1 to 4), Sakinaw Lake (5 to 6 and 11 to 12), Alouette Lake (7 to 9), Nimpkish Lake (10), and Sproat Lake (13 to 17). The numbers 1 to 9 and 10 to 17 on the $\mathrm{X}$-axis refer to kokanee and sockeye, respectively

Weber et al. (2002), found that the isotopic signature of sulfur in the otolith tends to be slightly lower than that found in the diet and muscle. Freshwater $\delta^{34} \mathrm{~S}$ in the otoliths of kokanee from Ruby and Sakinaw lakes was on average $1.8 \%$ and $3.1 \%$ lower than that observed in muscle. Weber et al. (2002) recorded a $\delta^{34} \mathrm{~S}$ value near zero $(-0.4 \pm 0.65 \%, 1 \mathrm{SE})$ in the zone of freshwater growth of the otolith of one wild juvenile Chinook salmon compared to values in the muscle of a number of wild juvenile Chinook salmon ranging from 1.0\% to $3.8 \%$. Except for Sakinaw sockeye, mean $\delta^{34} \mathrm{~S}$ differences between freshwater zooplankton and otoliths ranged from $0.1 \%$ to $4.4 \%$ and overlapped the range of differences observed by Weber et al. (2002).

This discrepancy between values of $\delta^{34} \mathrm{~S}$ in the freshwater diet and in otoliths might be due to seasonal and interannual variation of $\delta^{34} \mathrm{~S}$ in freshwater zooplankton as the dates of fish and prey collection did not match (Table 1). Irregularity and roughness of the otolith surface (to which SIMS is 
sensitive) can also play a minor role, but the consistency in the observed differences between our results and those of Weber et al. (2002) argues against a significant impact of surface topography. Finally, some unknown degree of sulfur isotopic fractionation could be potentially introduced by fish physiology. In this case, the instrumental mass fractionation correction that assumes a marine value of $20 \%$ for the outer edge of sockeye otoliths could be biased if there was sulfur isotopic fractionation between the marine diet and otoliths. Diverse organic components such as protein, glucose, and triglycerides have been analyzed in both the endolymph and blood plasma (Kalish 1991). However, comprehensive work on formation of the organic matrix of an otolith in relation to sulfurbased components is lacking. One possible explanation for the discrepancy might be a difference between the composition of the endolymph (which contains the compounds involved in the acellular growth of the otolith) and that of the blood (Payan et al. 1998), which presumably reflects the diet. Furthermore, one might expect some discrepancies between the endolymph and the otoliths since the organic matrix of the otolith is composed of both preformed proteins present in the endolymph and derived from a modification of protein precursors during otolith formation (Borelli et al. 2001). Finally, inorganic sulfur from the ambient water might be incorporated into the otolith (Mugiya and Iketsu 1987), modifying the relation of the isotopic signature of sulfur between the diet and the otolith.

Our measurements of $\delta^{34} \mathrm{~S}$ in fish tissues, freshwater zooplankton from the study lakes, and marine zooplankton from coastal British Columbia confirm the link between diet and the chemical life history of fish as recorded in their otoliths. However, it remains unclear why the freshwater isotopic signature of sulfur in otoliths tends to be somewhat lower than that of the diet.

Classification of samples of known and unknown origin

We built a quadratic discriminant function (QDF) to classify known ecotypes of $O$. nerka because the covariance matrix was not homogeneous between groups $\left(X^{2}=15.6, p<0.005\right)$. Density estimates of the training data set showed two well-defined groups, sockeye and kokanee, with no significant overlap. Not surprisingly, the error rate via crossvalidation was nil. Posterior probability distributions of the training data set exceeded $93 \%$ for both ecotypes with no classification error. This indicates that $\delta^{34} \mathrm{~S}$ in the core can be used to accurately assess the maternal origin of $O$. nerka.

To illustrate the application of $\delta^{34} \mathrm{~S}$ as a tool for assessing the origin of $O$. nerka, we applied the discriminant function from the training set to ten unidentified specimens collected from Sakinaw Lake as either kokanee or sockeye according to posterior probabilities based QDF and Bayes' theorem with equal prior probabilities. The $\delta^{34} \mathrm{~S}$ in the core and the first year of growth in these fish ranged from $0.4 \%$ o to $8.9 \%$ and $-0.1 \%$ o to $8.8 \%$ o, respectively, and averaged was $5.1 \pm 0.8 \%$ and $4.3 \pm 0.6 \%$, respectively (Fig. 6). This pattern is similar to that described for kokanee (Fig. 5). As such, the quadratic discriminant function classified those as kokanee with a posterior probability of at least $99 \%$ (Fig. 6).

Because $\delta^{34} \mathrm{~S}$ varies over a wider range $(55 \%)$ than other isotopes such as $\mathrm{C}$ and $\mathrm{N}$ (Barnes and

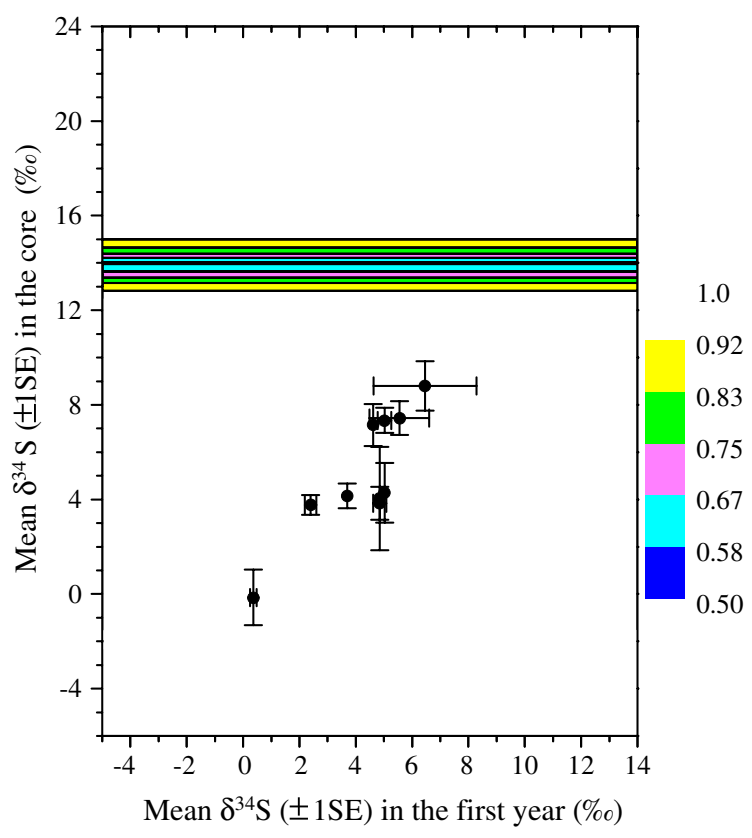

Fig. 6 Mean $\delta^{34} \mathrm{~S}( \pm 1 \mathrm{SE})$ in the core of the otolith is plotted against mean $\delta^{34} \mathrm{~S}$ in the first year of growth for specimens of unknown maternal origin from Sakinaw Lake. Contour plot of the posterior probabilities of a specimen being sockeye or kokanee based on a discriminant function using a $\delta^{34} \mathrm{~S}$ in the core. Values in the upper part of the plot indicate a high probability of being sockeye whereas values in the lower part indicate a high probability of being kokanee 
Jennings 2007), we expect that its use in otolith microchemistry will extend beyond the simple identification of maternal origin and basic life history pattern. $\delta^{34} \mathrm{~S}$ signatures in combination with other markers, in otolith and in the environment should enable researchers to describe the environmental history (diet and temperature) of individual fish and hence improve the resolution of the food web structure, habitat uses and fish migration.

In summary, stable sulfur isotope signatures as preserved in otoliths can successfully identify the maternal origin with high predictive power and hence discriminate among ecotypes of $O$. nerka. $\delta^{34} \mathrm{~S}$ in muscle has a similar potential (Doucett et al. 1999a) but the maternal signature in young-of-the-year fish is rapidly masked by the new diet, whereas it is faithfully recorded in otoliths. Thus, otoliths provide a useful chronology of fish habitats, whether artificial (hatchery) or natural (lake, stream and river). This can be a powerful tool in the evaluation of conservation approaches targeting anadromous Pacific salmon.

Acknowledgements This research greatly benefited from significant contributions from various individuals. We greatly appreciate the efforts of Lisa Wetzel and Kim Larsen in preparing otoliths, Tatiana Bruk for assistance with preparation of tissue samples and microphotography of otoliths, Jim Cameron for sampling in Sakinaw and Ruby lakes, Paul Rankin for providing zooplankton samples from Sproat and Woss lakes, Shannon Harris for zooplankton samples from Alouette Lake, Ron Tanasichuk for euphausiid samples, EmmaJane Johnson for otoliths of kokanee from Alouette Lake, Nicholas Duprey for Fig. 1, the staff of the PBS Ageing Lab for help with age determination, S. Mazumder at the University of Victoria for sulfur analysis, Ted Sweeten and Bill Bennett for use of their microscopes and cameras. We thank Peter Weber for useful discussions, two anonymous reviewers for their comments and suggestions, and Neil Bourne for his review. The UCLA ion microprobe laboratory is partially supported by a grant from the National Science Foundation Instrumentation and Facilities Program.

Open Access This article is distributed under the terms of the Creative Commons Attribution Noncommercial License which permits any noncommercial use, distribution, and reproduction in any medium, provided the original author(s) and source are credited.

\section{References}

Anderson TW (1984) An introduction to multivariate statistical analysis. Wiley, New York
Andersson P, Torssander P, Ingri J (1992) Sulphur isotope ratios in sulfate and oxygen isotopes in water from a small watershed in central Sweden. Hydrobiologia 235-236:205-217

Ault WU, Kulp JL (1959) Isotopic geochemistry of sulphur. Geochim Cosmochim Acta 16:201-235

Barnes C, Jennings S (2007) Effect of temperature, ration, body size and age on sulphur isotope fractionation in fish. Rapid Commun Mass Spectrom 21:1461-1467

Borelli G, Mayer-Gostan N, De Pontual H, Boeuf G, Payan P (2001) Biochemical relationships between endolymph and otolith matrix in the trout (Oncorhynchus mykiss) and turbot (Psetta maxima). Calcif Tissue Int 69:356-364

Burgner RL (1991) Life history of Sockeye Salmon (Oncorhynchus nerka). In: Groot C, Margolis L (eds) Pacific Salmon life histories. University of British Columbia Press, Vancouver, pp 1-117

Calmels D, Gaillardet J, Brenot A, France-Lanord C (2007) Sustained sulfide oxidation by physical erosion processes in the Mackenzie River basin: climatic perspectives. Geology 35:1003-1006

Caron F, Tessier A, Kramer JR, Schwarcz HP, Rees CE (1996) Sulfur and oxygen isotopes of sulfate in precipitation and lakewater, Quebec, Canada. Appl Geochem 1:601-606

Chanton JP, Lewis FG (1999) Plankton and dissolved inorganic carbon isotopic composition in a riverdominated estuary: Apalachicola Bay, Florida. Estuaries 22:575-583

Croisetière L, Hare L, Tessier A, Cabana G (2009) Sulphur stable isotopes can distinguish trophic dependence on sediments and plankton in boreal lakes. Freshwat Biol 54:1006-1015

De Brabandere L, Catalano MJ, Frazer TK, Allen MS (2009) Stable isotope evidence of ontogenetic changes in the diet of gizzard shad Dorosoma cepedianum. J Fish Biol 74:105-119

DeNiro MJ, Epstein S (1978) Influence of diet on the distribution of carbon isotopes in animals. Geochim Cosmochim Acta 42:495-506

Ding T, Valkiers S, Kipphardt H, De Bièvre P, Taylor PDP, Gonfiantini R, Krouse R (2001) Calibrated sulfur isotope abundance ratios of three IAEA sulfur isotope reference materials and V-CDT with a reassessment of the atomic weight of sulfur. Geochim Cosmochim Acta 65:24332437

Donohoe CJ, Adams PB, Royer CF (2008) Influence of water chemistry and migratory distance on ability to distinguish progeny of sympatric resident and anadromous rainbow trout (Oncorhynchus mykiss). Can J Fish Aquat Sci 65:1060-1075

Doucett RR, Hooper W, Power G (1999a) Identification of anadromous and nonanadromous adult brook trout and their progeny in the Tabusintac River, New Brunswick, by means of multiple-stable-isotope analysis. Trans Am Fish Soc 128:278-288

Doucett RR, Power M, Power G, Caron F, Reist JD (1999b) Evidence for anadromy in a southern relict population of Arctic charr from North America. J Fish Biol 55:8493

Edwards MS, Turner TF, Sharp ZD (2002) Short- and longterm effects of fixation and preservation on stable isotope 
values $\left(\delta^{13} \mathrm{C}, \delta^{15} \mathrm{~N}, \delta^{34} \mathrm{~S}\right)$ of fluid-preserved museum specimens. Copeia 4:1106-1112

Ethier ALM, Scheuhammer AM, Bond DE (2008) Correlates of mercury in fish from lakes near Clyde Forks, Ontario, Canada. Environ Pollut 154:89-97

Foote CJ, Wood CC, Withler RE (1989) A biochemical genetic study of the relationship between sockeye salmon and kokanee, the anadromous and nonanadromous forms of Oncorhynchus nerka. Can J Fish Aquat Sci 46:149-158

Fry B (1983) Fish and shrimp migrations in the northern Gulf of Mexico analyzed using stable $\mathrm{C}, \mathrm{N}$, and $\mathrm{S}$ isotope ratios. Fish Bull 81:789-801

Fry B (1988) Food web structure on Georges Bank from stable $\mathrm{C}, \mathrm{N}$, and $\mathrm{S}$ isotopic compositions. Limnol Oceanogr 33:1182-1190

Fuller RD, Mitchell MJ, Krouse HR, Wyskowski BJ, Driscoll CT (1986) Stable sulfur isotope ratios as a tool for interpreting ecosystem sulfur dynamics. Water Air Soil Pollut 28:163-171

Goldhaber MB, Kaplan IR (1974) The sulfur cycle. The sea. Wiley, New York

Gormly JR, Sackett WM (1977) Carbon isotope evidence for the maturation of marine lipids. In: Campos R, Goni J (ed) Advances organic geochemistry. Empresa Nac Endaro Invest, Mineras, Madrid, pp 321-339

Hartmann M, Nielsen H (1964) $\delta^{34} \mathrm{~S}$ Werte in rezenten Meeresedimenten and ihre Deutung am Beispiel einiger Sedimentprofile aus der west-lichen Ostsee. Geol Rundschau 58:621-655

Hesslein RH, Capel MJ, Fox DE (1988) Sulfur isotopes in sulfate in the inputs and outputs of a Canadian Shield watershed. Biogeochemistry 5:263-273

Hesslein RH, Capel MJ, Fox DE, Hallard KA (1991) Stable isotopes of sulfur, carbon, and nitrogen as indicators of trophic level and fish migration in the lower Mackenzie River basin, Canada. Can J Fish Aquat Sci 48:2258-2265

Hesslein RH, Hallard KA, Ramlal P (1993) Replacement of sulfur, carbon and nitrogen in tissue of growing broad whitefish (Coregonus nasus) in response to a change in diet traced by $\delta^{34} \mathrm{~S}, \delta^{13} \mathrm{C}$, and $\delta^{15} \mathrm{~N}$. Can J Fish Aquat Sci 50:2071-2076

Hoffman JC, Bronk DA, Olney JE (2007) Tracking nursery habitat use in the York River estuary, Virginia, by young American shad using stable isotopes. Trans Am Fish Soc 136:1285-1297

Kalish JM (1990) Use of otolith microchemistry to distinguish the progeny of sympatric anadromous and non-anadromous salmonids. Fish Bull 88:657-666

Kalish JM (1991) Determinants of otolith chemistry: seasonal variation in the composition of blood plasma, endolymph and otoliths of bearded rock cod Pseudophycis barbatus. Mar Ecol Prog Ser 74:137-159

Kang YJ, Stevenson AK, Yau PM, Kollmar R (2008) Sparc protein is required for normal growth of zebrafish otoliths. J Assoc Res Otolaryngol 9:436-451

Krouse H, Herbert M (1988) Sulphur and carbon isotope studies of food webs. University of Calgary, Archaeological Association, pp 315

Lackey RT, Lach DH, Duncan SL (2006) Wild salmon in western North America: forecasting the most likely status in 2100. In: Lackey RT, Lach DH, Duncan SL (eds) The future of wild Pacific Salmon. American Fisheries Society, Bethesda, pp 57-70

MacAvoy SE, Macko SA, Garman GC (1998) Tracing marine biomass into tidal freshwater ecosystems using stable sulfur isotopes. Naturwissenschaften 85:544-546

Marshall SL, Parker SS (1982) Pattern identification in the microstructure of sockeye salmon (Oncorhynehus nerka) otoliths. Can J Fish Aquat Sci 39:542-547

McCutchan JH Jr, Lewis WM Jr, Kendall C, McGrath CC (2003) Variation in trophic shift for stable isotope ratios of carbon, nitrogen, and sulfur. Oikos 102:378-390

McCutchan JH Jr, Lewis WM, Kendall C, McGrath CC (2005) Erratum: Variation in trophic shift for stable isotope ratios of carbon, nitrogen, and sulfur. (Oikos (2003) 102 (378390)). Oikos 111:416

Mitchell M, Mayer B, Bailey SW, Hornbeck JW, Alewell C, Driscoll CT, Likens GE (2001) Use of stable isotope ratios for evaluating sulfur sources and losses at the Hubbard Brook Experimental Forest. Water Air Soil Pollut 130:75-86

Morrison DF (1976) Multivariate statistical methods. McGrawHill, New York

Mugiya Y, Iketsu H (1987) Uptake of aspartic acid and sulfate by calcified tissues in goldfish and tilapia. Bull Fac Fish Hokkaido Univ 38:185-190

Naiman RJ, Bilby RE, Schindler DE, Helfield JM (2002) Pacific salmon, nutrients, and the dynamics of freshwater and riparian ecosystems. Ecosystems 5:399-417

Nriagu JO, Soon YK (1985) Distribution and isotopic composition of sulfur in lake sediments of northern Ontario. Geochim Cosmochim Acta 49:823-834

Nriagu JO, Rees CE, Mekhtiyeva VL, Lein AY et al (1991) In: Krouse HR, Grinenko VA (ed) Hydrosphere. Stable isotopes:natural and anthropogenic sulphur in the environment. John Wiley \& Sons, New York. SCOPE, vol 43, pp 177-265

Payan P, Borelli G, Boeuf G, Mayer-Gostan N (1998) Relationship between otolith and somatic growth: consequence of starvation on acid-base balance in plasma and endolymph in the rainbow trout Oncorhynchus mykiss. Fish Physiol Biochem 19:35-41

Perry KA, Pedersen TF (1993) Sulphur speciation and pyrite formation in meromictic ex-fjords. Geochim Cosmochim Acta 57:4405-4418

Peterson BJ, Fry B (1987) Stable isotopes in ecosystem studies. Annu Rev Ecol Syst 18:293-320

Peterson BJ, Howarth RW, Garritt RH (1985) Multiple stable isotopes used to trace the flow of organic matter in estuarine food webs. Science 227:1361-1363

Power M, Power G, Caron F, Doucett RR, Guiguer KRA (2002) Growth and dietary niche in Salvelinus alpinus and Salvelinus fontinalis as revealed by stable isotope analysis. Environ Biol Fishes 64:75-85

Rees CE, Jenkins WJ, Monster J (1978) The sulphur isotopic composition of ocean water sulfate. Geochim Cosmochim Acta 42:377-381

Rieman BE, Myers DL, Nielsen RL (1994) Use of otolith microchemistry to discriminate Oncorhynchus nerka of resident and anadromous origin. Can J Fish Aquat Sci 51:68-77 
SAS Institute (2008) SAS/STAT 9.2 User's guide: the GLM procedure. SAS, North Carolina, p 208

Sasaki A (1972) Variation in sulfur isotope composition of oceanic sulfate. 24th International Geological Congress Sect 10:342-345

Spence J, Telmer K (2005) The role of sulfur in chemical weathering and atmospheric $\mathrm{CO} 2$ fluxes: Evidence from major ions, $\delta^{13} \mathrm{C}_{\mathrm{DIC}}$, and $\delta^{34} \mathrm{~S}_{\mathrm{SO} 4}$ in rivers of the Canadian Cordillera. Geochim Cosmochim Acta 69:5441-5458

Taylor EB, Foote CJ, Wood CC (1996) Molecular genetic evidence for parallel life history evolution within a Pacific salmon (sockeye salmon and kokanee, Oncorhynchus nerka). Evolution 50:401-416

Thode HG (ed) (1991) Sulphur isotopes in nature and the environment: an overview. Wiley, pp 1-21

Thode HG, Monster J, Dunford HB (1961) Sulphur isotope geochemistry. Geochim Cosmochim Acta 25:159-174

Vander Zanden MJ, Hulshof M, Ridgway MS, Rasmussen JB (1998) Application of stable isotope techniques to trophic studies of age- 0 smallmouth bass. Trans Am Fish Soc 127:729-739

Volk EC, Blakley A, Schroder SL, Kuehner SM (2000) Otolith chemistry reflects migratory characteristics of Pacific salmonids: Using otolith core chemistry to distinguish maternal associations with sea and freshwaters. Fish Res 46:251-266
Walker KF, Likens GE (1975) Meromixis and a reconsidered typology of lake circulation patterns. Verh Int Verein Limnol 19:442-458

Weber PK, Hutcheon ID, McKeegan KD, Ingram BL (2002) Otolith sulfur isotope method to reconstruct salmon (Oncorhynchus tshawytscha) life history. Can J Fish Aquat Sci 59:587-591

Wells RJD, Cowan JH Jr, Fry B (2008) Feeding ecology of red snapper Lutjanus campechanus in the northern Gulf of Mexico. Mar Ecol Prog Ser 361:213-225

Wood CC, Bickham JW, Nelson RJ, Foote CJ, Patton JH (2008) Recurrent evolution of life history ecotypes in sockeye salmon: implications for conservation and future evolution. Evol Appl 1:207-221

Yang C, Telmer K, Veizer J (1996) Chemical dynamics of the "St. Lawrence" riverine system: $\delta \mathrm{D}_{\mathrm{H} 2 \mathrm{O}}, \delta^{18} \mathrm{O}_{\mathrm{H} 2 \mathrm{O}}, \delta^{13} \mathrm{C}_{\mathrm{DIC}}, \delta^{34}$ sulfate, and dissolved ${ }^{87} \mathrm{Sr} /{ }^{86} \mathrm{Sr}$. Geochim Cosmochim Acta 60:851-866

Zimmerman CE, Reeves GH (2000) Population structure of sympatric anadromous and nonanadromous Oncorhynchus mykiss: evidence from spawning surveys and otolith microchemistry. Can J Fish Aquat Sci 57: 2152-2162

Zimmerman CE, Reeves GH (2002) Identification of steelhead and resident rainbow trout progeny in the Deschutes River, Oregon, revealed with otolith microchemistry. Trans Am Fish Soc 131:986-993 